\title{
An Analysis of the Current Situation of the Employed Youth in China on Wealth Concept and Its Influencing Factors - Based on a Nationwide Survey of 439 Young Employees
}

\author{
Xiaohong Xian ${ }^{1}$, Qingxiang Feng ${ }^{2}$ \\ ${ }^{1}$ School of Marxism, Central University of Finance and Economics, Beijing, China \\ ${ }^{2}$ Institute of Guangdong Hong Kong and Macau Development Studies, Sun Yat-sen University, Guangzhou, China \\ Correspondence: Qingxiang Feng, Institute of Guangdong Hong Kong and Macau Development Studies, Sun Yat-sen \\ University, Guangzhou, China.
}

Received: March 11, 2020

doi:10.11114/ijsss.v8i3.4813

\author{
Accepted: March 30, $2020 \quad$ Available online: April 8, 2020 \\ URL: https://doi.org/10.11114/ijsss.v8i3.4813
}

\begin{abstract}
This research conducted a sample survey of 439 young employees in different industries and fields in 7 provinces and municipalities in North China, Central China, East China, South China, Northeast China, Northwest China, and Southwest China. Through data analysis, it found that the mainstream of the employed youth held a positive concept of wealth, while a few of them had issues such as money worship, hedonism, and hatred or envy towards the rich. There are significant differences in wealth cognition, wealth creation, wealth consumption, and wealth distribution among young employees of different genders, regions and units as well as with different numbers of children. And the main influencing factors of their wealth concept appear to be the complex social environment, the differences in personal cognition and thinking modes, the absence of wealth education, and the impact of internet culture.
\end{abstract}

Keywords: China, the employed youth, wealth concept, influencing factors

\section{Research Introduction}

\subsection{Research Background and Significance}

As an inevitability contained in the comprehensive interweaving of human interdependence (Hegel, 2009), wealth has always been the center of people's attention and favor, as it is not only closely related to people's lives but also tightly linked to economic development. The wealth concept is the general and basic views of people on wealth and relevant issues, as well as an integral part of the outlook on life and values. The younger generation, as the "new force and backbone of China's economic and social development", represent the future and hope of China and the Chinese nation (CPC Central Committee \& State Council, 2017). Young people have formed different views on wealth based on their understanding and perception of the relevant issues under different historical conditions. Currently, China is at a critical stage of comprehensively deepening its reform, with more frequent fusions of various ideologies and cultures and more diversified values, which has correspondingly led to the dramatic changes in the attitude of the youth towards wealth. The employed youth is an integral part of the youth group and the mainstay of wealth creation in society, whose wealth concept reflects the wealth and value orientation of the dominant class in the whole society both at present and in the future. Studying the situation of the employed youth on wealth concept and analyzing the group differences of different young employees in this regard will help the group establish a correct concept of wealth and provide valuable reference for the Chinese government to formulate and improve policies concerning youth development.

\subsection{Research Objects and Research Methods}

The study of the wealth concept of the employed youth in China today in this paper focused on the attitudes, views, and behaviors of young employees in terms of wealth cognition, wealth creation, wealth consumption, and wealth distribution. Regarding the definition of the youth, this study refers to the definition provided in the National Medium and Long-term Youth Development Plan (2016-2025) (hereinafter referred to as the Plan) issued by the CPC Central Committee and the State Council: 14-35-year-olds.

In this study, 439 young people working in state organs, state-owned enterprises, public institutions and private 
enterprises were randomly selected from North China, Central China, East China, South China, Northeast China, Northwest China, and Southwest China as research objects. Among them, 73 persons are from Beijing, 59 from Hubei, 69 from Shanghai, 43 from Guangdong, 72 from Jilin, 62 from Gansu, and 61 from Guizhou. A total of 513 questionnaires have been handed out, and after eliminating 74 with more missing values, 439 valid samples have been obtained, reporting an effective rate of $85.41 \%$. Of the valid samples, 189 are men, accounting for $43.05 \%$; 250 are women, taking up 56.95\%, with the average age of the respondents being 28.95 years. Although the sample cannot cover all working youth in China, it provides reasonable sample region and male-female ratio, which, to some extent, can reflect the current situation of young employees on wealth concept in China. After the samples were collected, the basic data were processed to run orientation and score analysis to reveal the current status of the young employees on wealth concept; the chi-square test, $\mathrm{T}$ test and others were used to conduct difference analysis of their wealth views; and the factor analysis method was adopted to understand the related influencing factors.

\section{The Current Situation of the Employed Youth on Wealth Concept}

\subsection{Wealth Cognition of the Employed Youth}

Through the design of two questions, "Regarding money, how do you think" and "In view of the descriptions of material wealth and spiritual wealth below, which view do you agree with more", this study has attempted to grasp the perception of the relationship between money, material wealth and spiritual wealth of Chinese youth today.

2.1.1 The Majority of the Employed Youth Tended to Have an Objective and Rational Outlook on Money, While a Few Leaned Towards Money Worship

The survey in Table 1 shows that most of the working young people tend to have an objective and rational view of money, while a few of them indicate a tendency towards money worship. Regarding money, $44.19 \%$ of the employed youth agreed that "money is the material basis of life, but not the whole of it"; $33.94 \%$ believed that "Money is not everything, but without money, everything is nothing"; 9.11\% thought "Money makes the world go around"; $7.29 \%$ considered "Money is mere worldly possession, you can't take it to your tomb"; and 5.47\% regarded "money as the source of all evil."

Table 1. Attitudes of the employed youth towards money

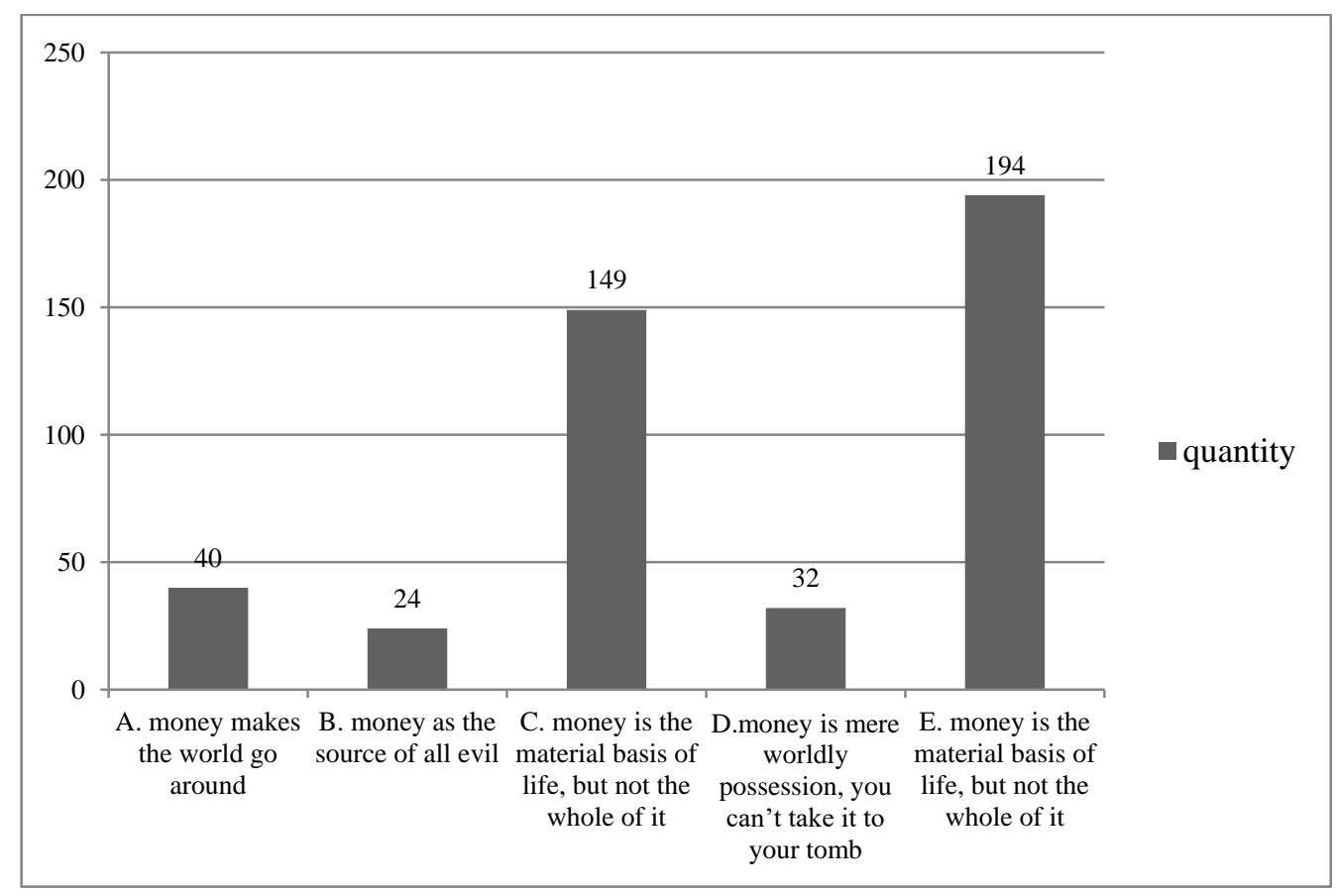

2.1.2 The Mainstream of the Employed Youth Acknowledged that Material Wealth and Spiritual Wealth Were Equally Important, While There Were also a Few who Valued Materiality over Spirituality

The survey in Table 2 shows that the vast majority of working young people is able to view the relationship between material and spiritual wealth properly, while some of them have misconception of wealth. $60.14 \%$ of the employed youth agreed that "material wealth and spiritual wealth are equally important"; $18.91 \%$ of them believed "spiritual wealth is 
more important than material wealth"; $11.62 \%$ considered "material wealth out values spiritual wealth as the latter is intangible"; $9.34 \%$ thought that "wealth only includes material wealth, not spiritual wealth."

Table 2. Attitudes of the employed youth towards material wealth and spiritual wealth

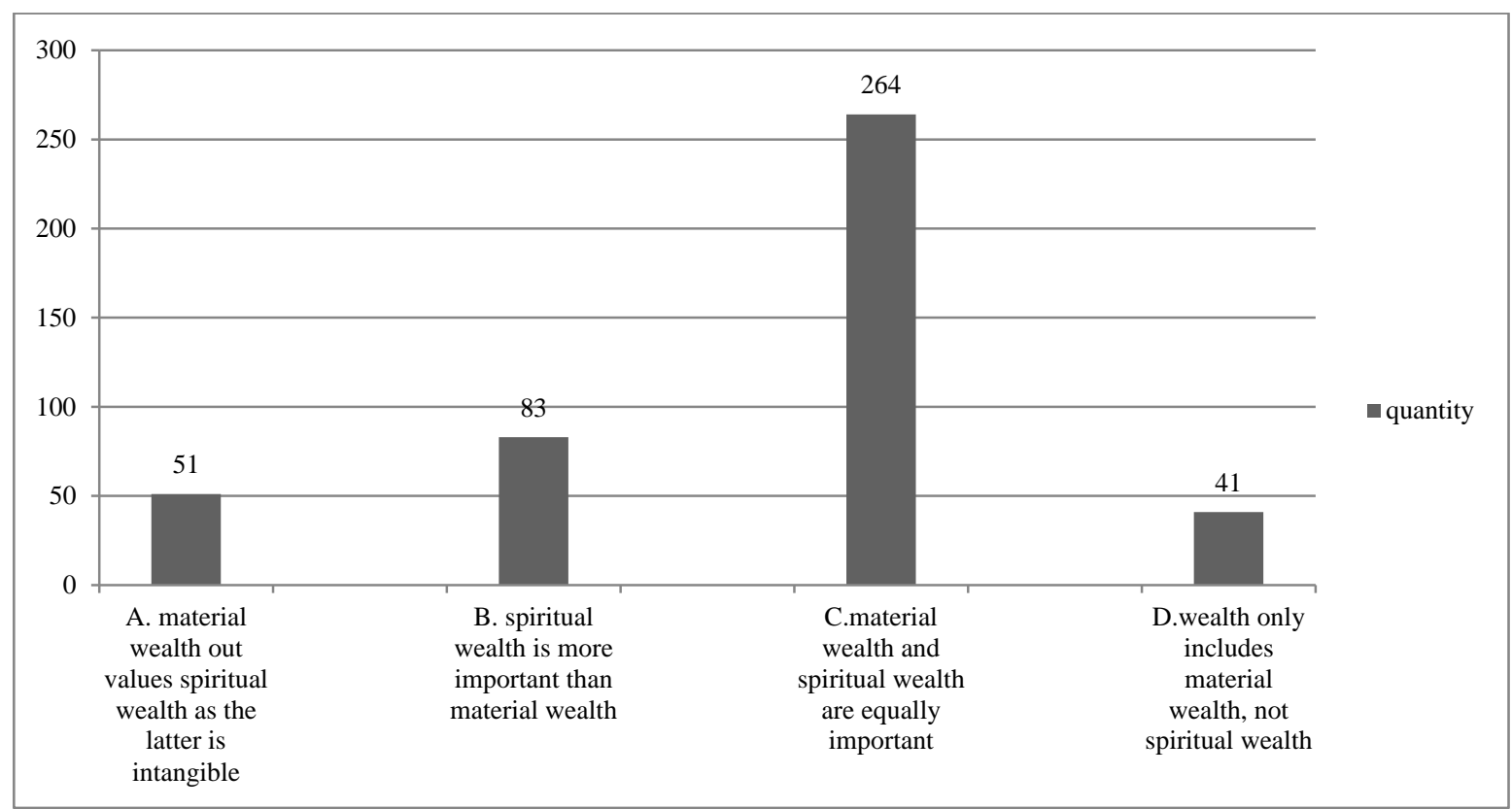

\subsection{Wealth Creation of the Employed Youth}

This study attempted to learn about the current view of the working young people on wealth creation through asking the following three questions: "How much do you agree with the following expressions", "From the perspective of wealth creation, how do you think of the Peking University grad's unconventional path to become a billion-dollar chairman through selling pork?", and "What's your opinion on the news that with a salary of 896,000 to 2.01 million yuan, Huawei has hired 8 fresh doctoral students of 2019 in artificial intelligence-related majors such as the Internet of Things, software, computational mathematics, big data, and so on, which has aroused heated discussions?"

Table 3. Attitudes of the employed youth towards wealth creation

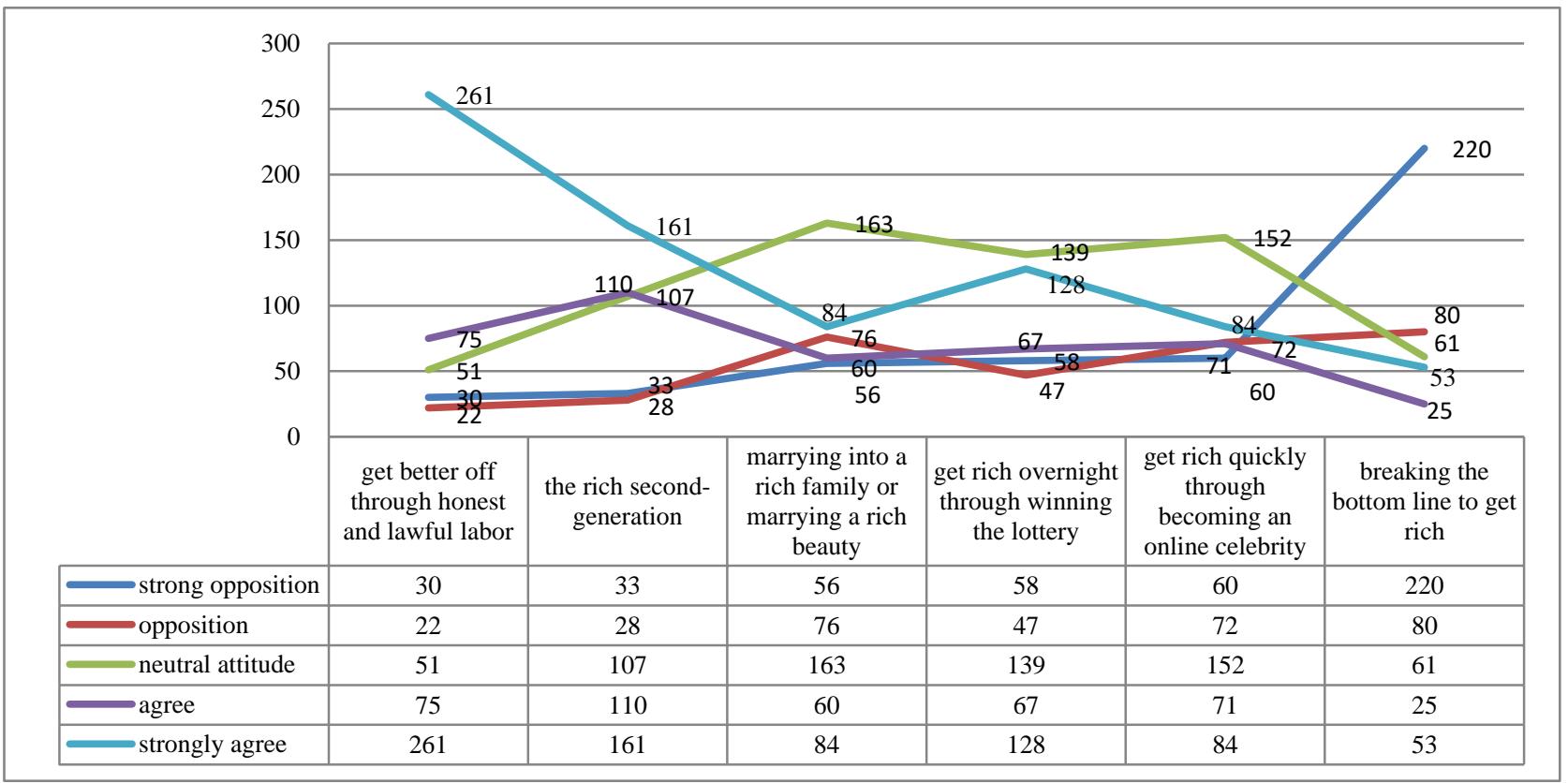




\subsubsection{The Coexistence of the Belief in Getting Rich by Hard Work and the Admiration of Reaping without Sowing}

The survey in Table 3 suggests that currently, $76.53 \%$ of the employed youth agree to "get better off through honest and lawful labor"; meanwhile, $61.73 \%$ of them hope to become "the rich second-generation"; $44.42 \%$ desire to "get rich overnight through winning the lottery"; $35.3 \%$ aspire to "get rich quickly through becoming an online celebrity"; $32.8 \%$ wish to change their destiny by "marrying into a rich family or marrying a rich beauty". It follows that most young workers believe in labor to create wealth. However, with the increasing diversification of the means to create wealth, a small number of those youths are eager to get rich quickly and at low cost through "inheritance of wealth", "lottery luck" and "marriage to rich families", which reflects the current money-worship trend among some young employees.

\subsubsection{Wealth Creation Through Innovation and Technology will Lead the New Trend of Creating Wealth}

According to the survey, in view of the "Peking University grad's unconventional path to become a billion-dollar chairman through selling pork", $55.35 \%$ of the employed youth believed that "the creation of wealth cannot be separated from both hard work and reform and innovation"; while concerning "Huawei's hiring of fresh doctoral students with high salaries", $55.58 \%$ of them thought that "the creation of wealth through technology will lead the trend of future wealth creation". It can be seen that with the development of the economy and technology, innovation and technology are increasingly becoming the boosters of wealth creation, and the working young people are having better awareness and perception of this fact.

\subsection{Wealth Consumption of the Employed Youth}

According to the survey that currently, $72.67 \%$ of the employed youth saw their income comes from salary and welfare; $48.06 \%$ of them maintained a monthly expenditure of 2000-5000 yuan, $23.69 \%$ kept their monthly expense below 2000 yuan, while $18 \%$ reported a monthly spending of 5,000-10,000 yuan. The top 5 items in the monthly expenditure ranking were: food, clothing, mortgages, transportation \& communications, and entertainment. By asking two questions, "How much do you agree with the following expressions" (Table 4) and "What's your view on the invisible poor population in the current youth group", this study tried to understand the current wealth consumption outlook of the young workers in China.

2.3.1 The Mainstream of the Employed Youth Agreed with Thrift and Green Consumption, while a few of them Were Extravagant, Wasteful and Overspending

Thrift is the traditional virtue of the Chinese nation, as well as a rational and civilized modern lifestyle. However, as life is getting better amid the continuous improvement of social productivity, do we still need to remain "thrifty" or should we put this virtue on the shelf? The survey presented, $53.53 \%$ of the respondents "strongly agree" with regard to the view that "thrift is the traditional virtue of the Chinese nation, and is still worth advocating", $23.46 \%$ of them said they "agree", and $12.53 \%$ of them expressed "neutral attitude", with only $4.33 \%$ showing "opposition" and $6.15 \%$ "strong opposition".

Green consumption, as a proper and healthy modern consumption way and concept representing harmonious development between human and nature, has developed rapidly and become more and more popular among young people under the advocacy of the state in recent years. Regarding the concept that "consumers must not only consider their own needs, but should also pay attention to health, green and environmental issues", the survey showed that $59.45 \%$ of the respondents said they "strongly agree", 19.36\% of them expressed "agree", 10.71\% held a "neutral attitude", while those voicing "opposition" and "strong opposition" both accounted for 5.24\%. It seems that currently, young workers generally approve of green consumption to a high degree, while only a few have expressed objection.

\subsubsection{Some Employed Youths Had a Tendency to Pursue Enjoyment Consumption and Excessive Consumption}

Enjoyment consumption is based on people's needs for enjoyment, which are needs for spiritual happiness and satisfaction on the fulfillment of survival needs (Chinese Academy of International Trade and Economic Cooperation under the Ministry of Commerce, 2018). With the enlarging number of high-income groups, the demand of the employed youth for material and spiritual consumption is also increasing. The survey in Table 4 shows that $29.38 \%$ of working young people acknowledge (strongly agree + agree) with the view that "modern men should enjoy life to the full and spend money freely", and $35.31 \%$ of them remain "neutral"; regarding the concept of "consumption is spending today's money to realize tomorrow's dreams", $25.74 \%$ of young workers express agreement (strongly agree + agree), and $34.85 \%$ take a "neutral" stand. The data in Table 5 further demonstrate that for "the invisible poor population" (Internet buzzwords) among youth groups, $11.62 \%$ of young employees express "envy, as they live a fine life with enough to eat and drink". It appears that at present, a considerable number of working young men agree with or even pursue enjoyment consumption, especially material joy. And those "invisible poor youth" go further to live a superficially superb life through borrowing, which is a typical manifestation of hedonism. 
Table 4. Attitudes of the employed youth towards wealth consumption

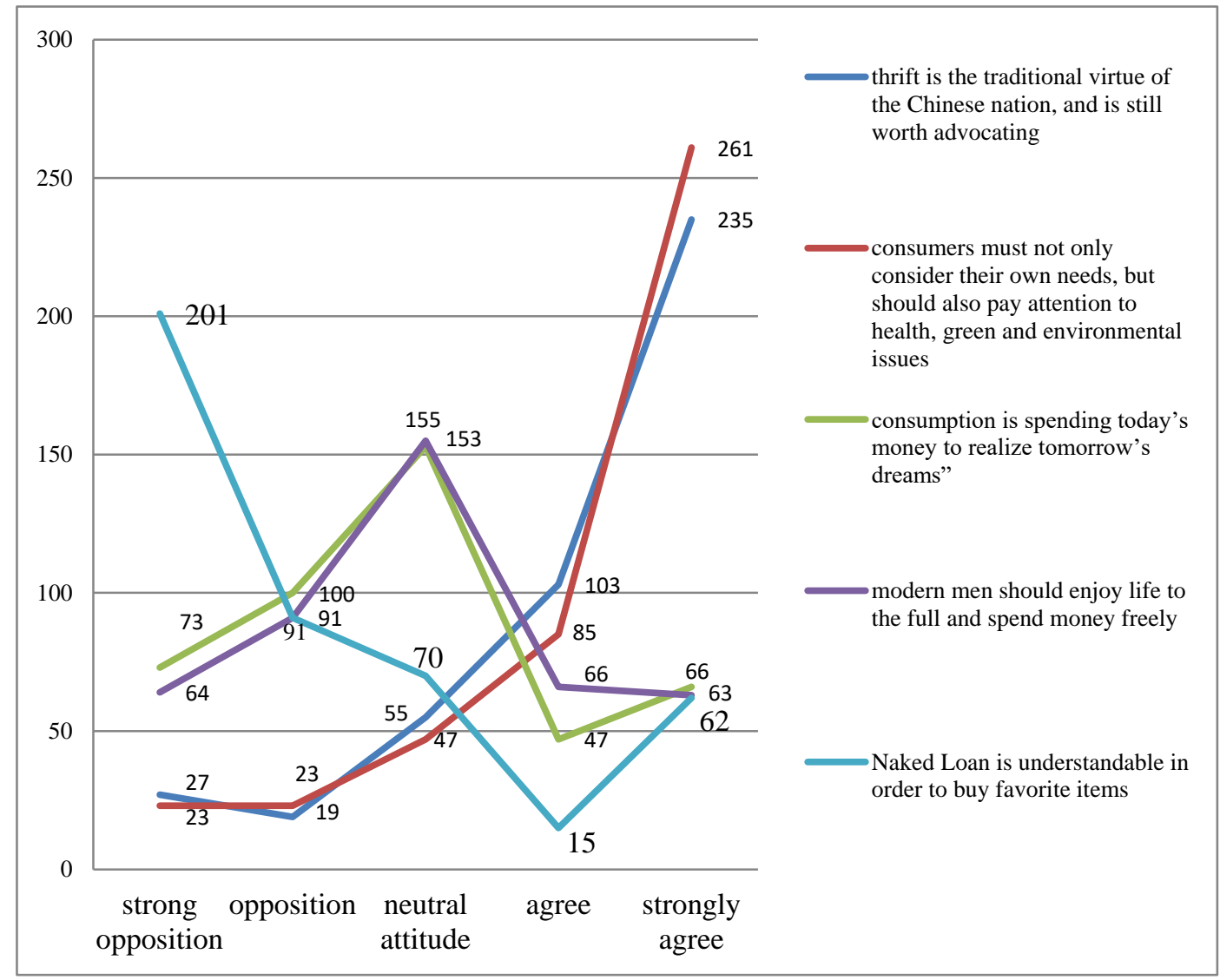

Table 5. Attitudes of the employed youth towards the "invisible poor population"

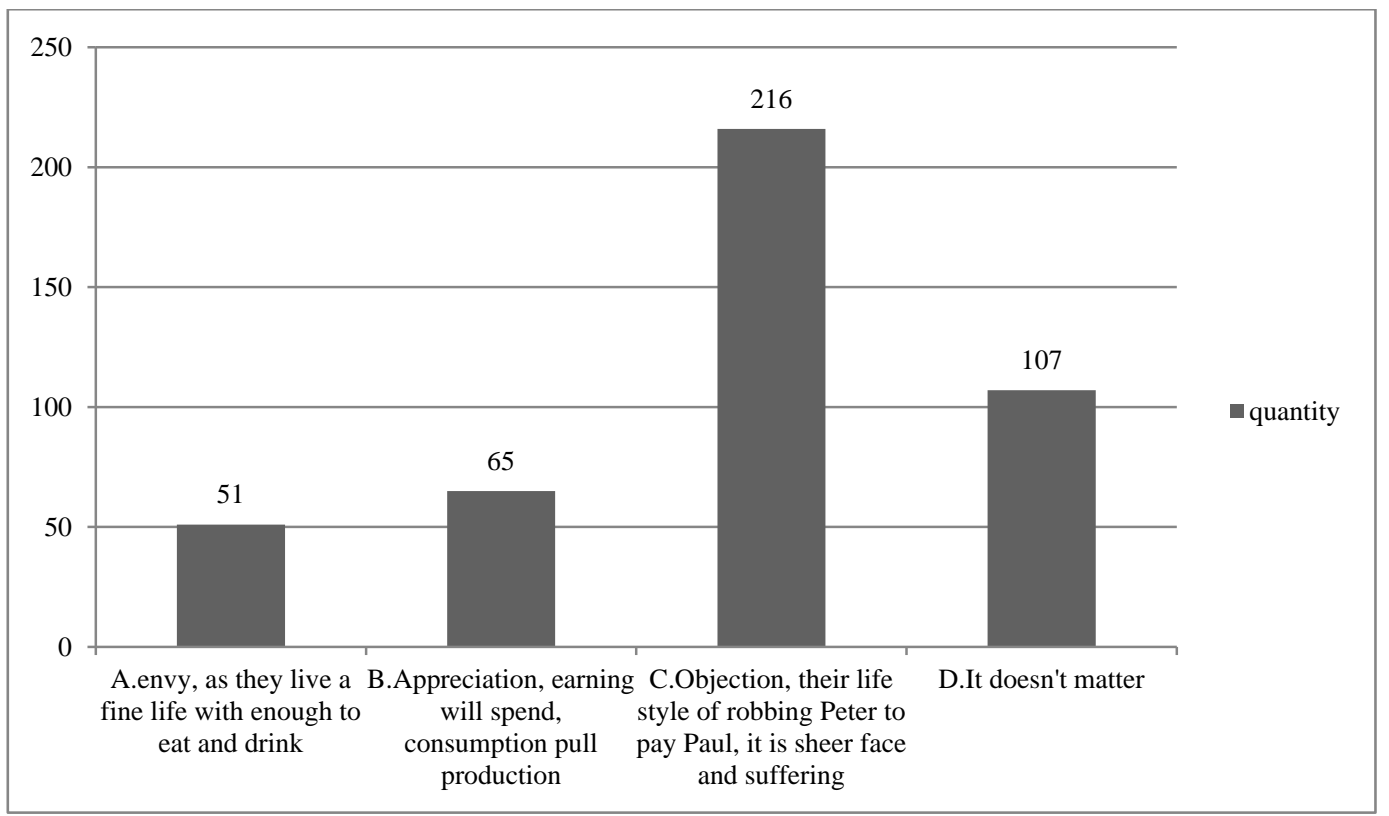




\subsection{Wealth Distribution of the Employed Youth}

By putting forward the two questions of "How do you think about the sky-high remuneration of stars", and "In the face of colleagues and friends with wealthy family backgrounds and generous spending, you will usually", this study attempted to understand the views of the current young employees in China on the issue of social wealth distribution.

2.4.1 Most of the Employed Youth Looked at the Distribution of Social Wealth Objectively and Rationally, While a Few Harbored Envy or Hatred Towards the Rich

Table 6. The attitudes of the employed youth towards acquaintance with wealthy family backgrounds and generous spending

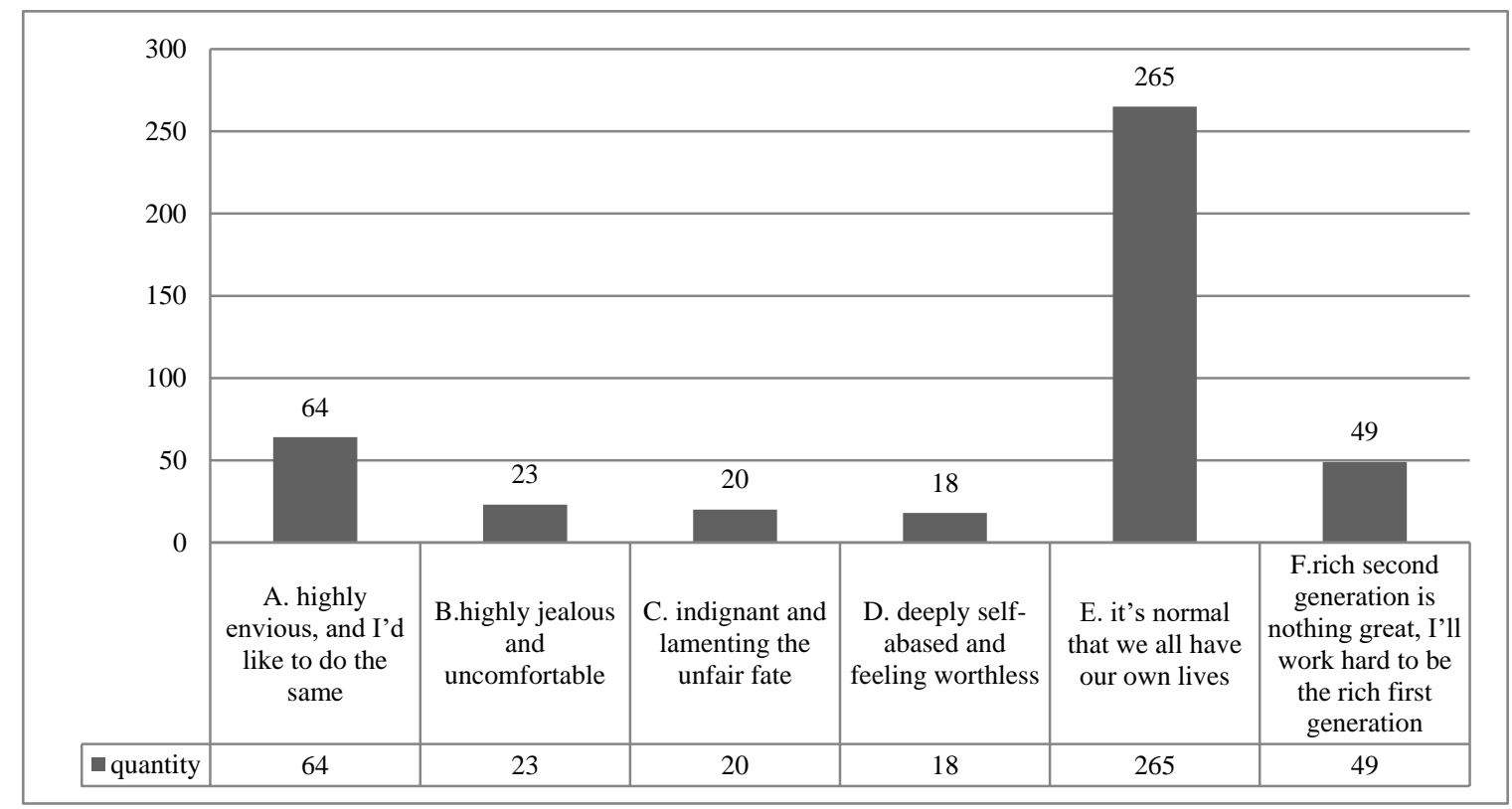

As young people enter the workforce, they may find the income and expenditure gaps between them and colleagues or friends around them become more and more prominent, which also reflects the distribution of wealth in the society. With the rise of those youths' cognitive level and the improvement of social wealth distribution system, the current mainstream of the employed youth can view the social wealth distribution situation around them in an objective and rational manner. The survey data in Table 6 indicates that in the face of "friends and colleagues with wealthy family backgrounds and generous spending", 265 interviewees state that "it's normal that we all have our own lives", accounting for $60.36 \%$ of the total; those with attitudes such as "highly jealous and uncomfortable", "indignant and lamenting the unfair fate" and "deeply self-abased and feeling worthless" take up 5.24\%, 4.56\%, and 4.1\%, respectively. It can be seen that the majority of the employed youth are able to view the gap between the rich and poor in society in a more objective and rational way, while only a few harbour envy or hatred towards the wealthy. In addition, $14.58 \%$ of the respondents express "strong envy" towards their colleagues and friends from rich families who spend generously, saying "they'd also like to do the same", which reflects that the mentality of "desiring to be rich and envious of the rich" existing in some young workers today.

2.4.2 Compared with "Distribution on the Basis of Labor", most of the Employed Youth Paid More Attention to "Distribution According to Contribution"

As the core of wealth distribution is the adjustment of interest relationships (Xianda Chen, 2010), so behind the views of the young employees on wealth distribution lie their perception and understanding of the current social interest relationship adjustment. According to the survey data in Table 7 about the attitudes towards the sky-high remuneration of some stars, $44.65 \%$ of the respondents think that "compared to scientists like Tu Youyou and Yuan Longping, the high income of stars is not proportional to their social contribution"; $20.96 \%$ of them believe that "the high rewards of stars are absurd, which will further widen the gap between the rich and the poor"; $19.13 \%$ state that "it's understandable as the astronomically high rewards of stars are also earned by their labor"; and 15.26\% expressed "paying no attention to these things." It shows that currently, the employed youth are not blindly jealous of or against the high-income groups, but are concerned about whether such high-income is directly proportional to their social contribution. 
Table 7. Attitudes of the employed youth towards the "sky-high remuneration of stars"

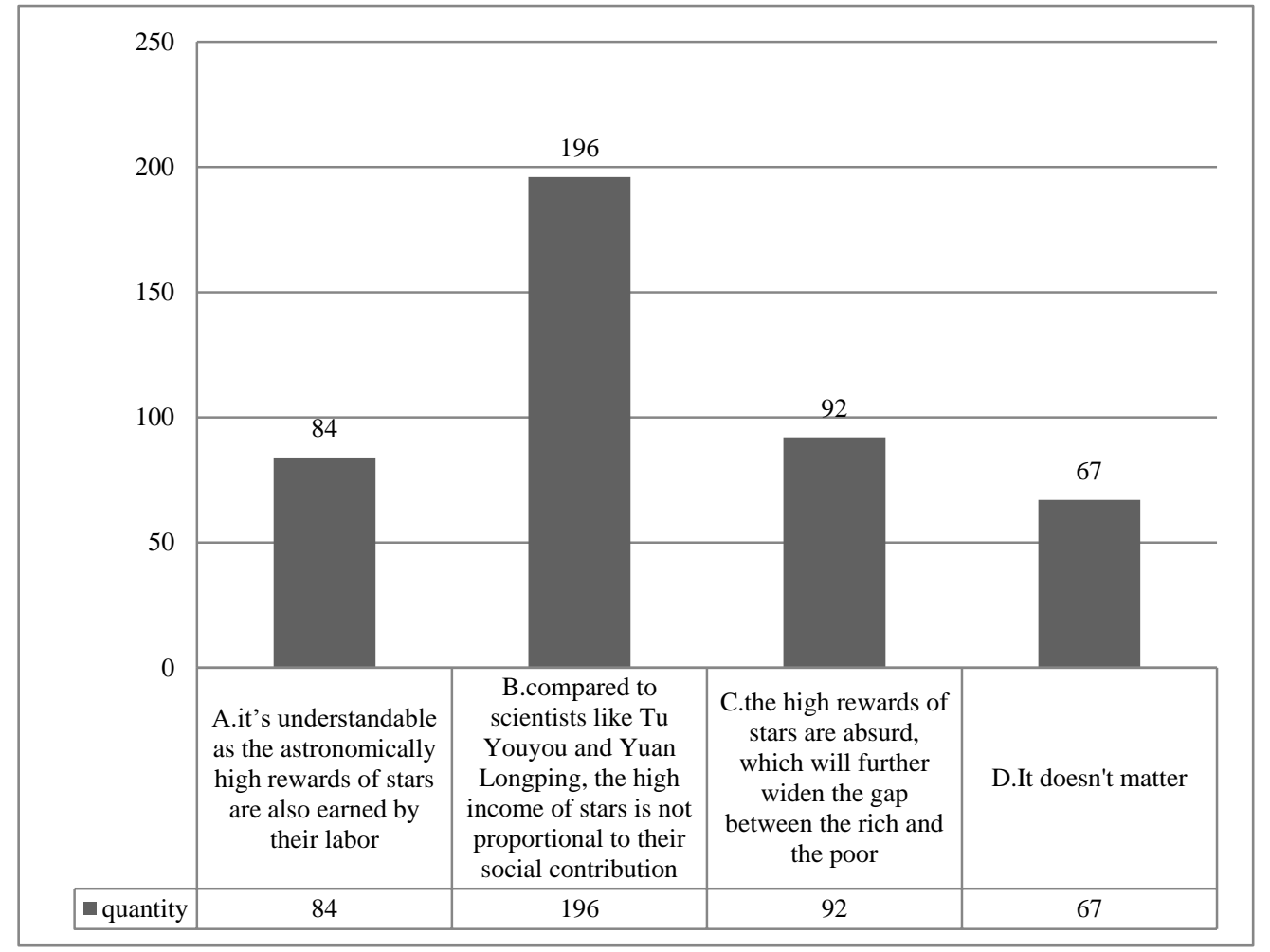

\section{The Group Difference Analysis of the Employed Youth on Wealth Concept}

This study analyzed the survey data through Chi-square test and T-test, and found that there were significant differences in the employed youth in China today in terms of gender, being only-child or not, the nature of work unit, and the number of children (see Appendix 8-11 for details).

\subsection{Significant Differences in Wealth Concept among the Employed Youth of Different Genders}

The differences in wealth concept between working young females and males are reflected in their wealth cognition, wealth creation and wealth consumption.

\subsubsection{Wealth Cognition}

Data analysis showed that there was a significant difference in wealth perceptions between working young females and males $(\mathrm{p} 1=\mathrm{p} 2=0.019<0.05)$.

(1) Young men valued material wealth such as money more than women. $10.1 \%$ of young men agreed that "Money makes the world go around", $1.7 \%$ higher than that of women; $15.9 \%$ of young men believed that "material wealth out values spiritual wealth as the latter is intangible", 7.5\% higher than women; and $12.2 \%$ of young men thought that "wealth only includes material wealth, not spiritual wealth", $4.6 \%$ higher than women.

(2) Compared with young men, young women agreed more with the equal importance between material wealth and spiritual wealth. $65.2 \%$ of young women thought "material wealth and spiritual wealth are equally important", $11.8 \%$ higher than that of men; $18.8 \%$ of those girls believed that "spiritual wealth is more important than material wealth", $0.3 \%$ higher than men.

\subsubsection{Wealth Creation}

Data analysis revealed that there were differences in wealth creation between working young males and females. Specifically, notable differences were found between young men and women in breaking the bottom line to get rich $(\mathrm{T}=$ $3.815 \mathrm{p}<0.001)$, and marrying into a wealthy family or with a rich beauty $(\mathrm{T}=2.317 \mathrm{p}<0.001)$; and there were no differences in creating wealth by labor $(\mathrm{T}=-1.211 \mathrm{p}>0.05)$, becoming the rich second-generation $(\mathrm{T}=-0.268 \mathrm{p}>0.05)$, winning the lottery $(\mathrm{T}=1.914 \mathrm{p}>0.05)$, and becoming an online celebrity $(\mathrm{T}=0.047 \mathrm{p}>0.05)$.

The employed young men were more likely than women to agree with "as long as they can make a fortune, it is acceptable to break the bottom line" $\left(M_{m}\right.$ 2.41> $\left.M_{f} 1.9\right)$; and young males were more inclined to change their fate 
through "marriage into a wealthy family or with a rich beauty" $\left(\mathrm{M}_{\mathrm{m}} 3.26>\mathrm{M}_{\mathrm{f}} 2.98\right)$.

\subsubsection{Wealth Consumption}

According to data analysis, there were differences in wealth consumption between working young males and females. Specifically, there were obvious differences in terms of thrift $(T=-1.223 \mathrm{p}<0.01)$, green consumption $(\mathrm{T}=-2.179 \mathrm{p}<0.01)$, and irrational borrowing consumption $(\mathrm{T}=2.944 \mathrm{p}<0.01)$; while no differences were found in excessive consumption $(\mathrm{T}=1.313 \mathrm{p}>0.05)$ and enjoyment consumption $(\mathrm{T}=0.878 \mathrm{p}>0.05)$.

On the whole, working young women scored higher than young men in the two aspects of viewing "thrift is the traditional virtue of the Chinese nation, which is still worth promoting" $\left(\mathrm{M}_{\mathrm{f}}=4.19>\mathrm{M}_{\mathrm{m}}=4.05\right)$ and "consumers must not only consider their own needs, but should also pay attention to health, green and environmental issues" $\left(\mathrm{M}_{\mathrm{f}}=4.34>\right.$ $\mathrm{M}_{\mathrm{m}}=4.10$ ); but they obtained a lower mark in terms of "Naked Loan is understandable in order to buy favorite items" $\left(\mathrm{M}_{\mathrm{f}}=2.02<\mathrm{M}_{\mathrm{m}}=2.14\right)$.

\subsection{Significant Differences in Wealth Concept among the Employed Youth in Different Regions}

According to data analysis, there were significant differences in wealth cognition, wealth creation, wealth consumption and wealth distribution among the employed youth in different regions. Specifically:

\subsubsection{Wealth Perception}

The survey showed that there were remarkable differences in wealth perception among young workers in different regions ( $\mathrm{p} 1=0.017<0.05, \mathrm{p} 2=0.005<0.05)$.

(1)Young employees in Beijing were more aware of the importance of both material and spiritual wealth. 79.5\% of young workers in Beijing agreed with the view that "material and spiritual wealth are equally important", reporting a higher proportion than those in other regions.

(2)Young people working in Guizhou valued material wealth such as money more than others. Among the investigated young employees in Guizhou, $21 \%$ took side with the view that "Money makes the world go around", showing a higher proportion than those in other regions; $25.8 \%$ believed that "Material wealth out values spiritual wealth as the latter is intangible", also higher than other regions; and 30.6\% considered that "wealth only includes material wealth, not spiritual wealth", still higher than other regions.

\subsubsection{Wealth Creation}

Data analysis revealed that differences existed in wealth creation among the employed youth in different cities. In specific terms, there were significant differences among young employees in different cities in creating wealth through labor $(\mathrm{F}=19.964 \mathrm{p}<0.05)$, making a fortune through breaking the bottom line $(\mathrm{F}=27.740 \mathrm{p}<0.001)$, and becoming the rich second-generation $(\mathrm{F}=9.244 \mathrm{p}<0.001)$; while no difference is noted in marriage into a wealthy family or with a rich beauty $(F=0.361 p>0.05)$, winning the lottery $(F=1.398 p>0.05)$, and becoming an online celebrity $(F=1.364 p>$ $0.05)$.

The employed youth in Jilin Province identified more with the view that "people should create wealth through honest and lawful labor" (M=19.964); and their counterparts in Gansu Province agreed more with "as long as they can make a fortune, it is acceptable to break the bottom line" $(\mathrm{M}=3.30)$; while those in Shanghai preferred that "if possible, I'd also like to be a rich second generation" $(\mathrm{M}=2.44)$.

\subsubsection{Wealth Consumption}

Data analysis showed that differences existed in wealth consumption among the employed youth in different cities. To be specific, young workers in different cities displayed notable differences in terms of thrift $(\mathrm{F}=17.334 \mathrm{p}<0.001)$, green consumption $(\mathrm{F}=27.740 \mathrm{p}<0.001)$, enjoyment consumption $(\mathrm{F}=3.262 \mathrm{p}<0.01)$ and irrational borrowing consumption $(\mathrm{F}=15.747 \mathrm{p}<0.001)$; and no difference was found in excessive consumption $(\mathrm{F}=2.029 \mathrm{~F} \mathrm{p}>0.05)$.

Jilin's young workers favored the view that "thrift is the traditional virtues of the Chinese nation and it is still worth promoting" $(\mathrm{M}=4.54)$ and "consumers must not only consider their own needs, but should also pay attention to health, green and environmental issues" $(\mathrm{M}=4.67)$; Working youth in Guizhou Province agreed more that "modern men should enjoy life to the full and spend money freely" $(\mathrm{M}=3.32)$ and "Naked Loan is also understandable in order to buy favorite items" $(\mathrm{M}=3.19)$.

\subsubsection{Wealth Distribution}

According to data analysis, differences existed in wealth distribution among the employed youth in different cities. Specifically, regarding "in the face of colleagues and friends with wealthy family backgrounds and generous spending", Shanghai youths took the lead with the highest percentage of $21.7 \%$ expressing "highly envious, and I'd like to do the same"; the young workers in Gansu accounted for the highest proportions of $18 \%, 13.1 \%, 13.1 \%$ and $19.7 \%$ saying they 
were "highly jealous and uncomfortable", "indignant and lamenting the unfair fate", "deeply self-abased and feeling worthless" and "rich second generation is nothing great, I'll work hard to be the rich first generation"; and those in Hubei Province reported the highest percentage of $81.4 \%$ stating "it's normal that we all have our own lives".

\subsection{Significant Differences in Wealth Concept among the Youth Working for Units of Different Nature}

There were differences in the wealth concept of young people working for employers of different nature, which were reflected in wealth perception, wealth creation and wealth distribution.

\subsubsection{Wealth Cognition}

Data analysis suggested that due to the different nature of units, there were significant differences among the young workers in their cognition of wealth ( $\mathrm{p} 1=0.001<0.05, \mathrm{p} 2=0.024<0.05 \mathrm{~s})$.

(1)The youth employed by public institutions have a more objective and rational outlook on wealth. $53.1 \%$ of youth in public institutions believed that "money is the material basis of life, but not the whole of it", which was remarkably higher than those working for other employers; $23.5 \%$ of them thought that "spiritual wealth is more important than material wealth", higher than those employed in other units.

(2) Self-the employed youths valued material wealth above all else. $19.6 \%$ of the self-the employed youths considered that "wealth only includes material wealth, not spiritual wealth", which was higher than those working in other units.

\subsubsection{Wealth Creation}

Data analysis showed that differences existed in wealth creation among the youth working for units of different nature. In specific terms, there were significant differences in creating wealth through labor $(\mathrm{F}=2.596 \mathrm{p}<0.05)$, making a fortune through breaking the bottom line $(\mathrm{F}=6.080 \mathrm{p}<0.001)$, and becoming the rich second-generation $(\mathrm{F}=4.589$ $\mathrm{p}<0.001)$; while no difference was reported in marriage into a wealthy family or with a rich beauty $(\mathrm{F}=1.587 \mathrm{p}>0.05)$, winning the lottery $(\mathrm{F}=1.852 \mathrm{p}>0.05)$, and becoming an online celebrity $(\mathrm{F}=1.368 \mathrm{p}>0.05)$.

Young people working in private enterprises agreed more with the view that "people should create wealth through honest and lawful labor" ( $\mathrm{M}=4.33)$ and "if possible, I'd also like to be a rich second generation" $(\mathrm{M}=411)$; while those self-employed tended to identify more with "as long as they can make a fortune, it is acceptable to break the bottom line" $(\mathrm{M}=2.61)$.

\subsubsection{Wealth Distribution}

According to data analysis, there were obvious differences among the young workers working for units of different natures in their perception of wealth $(\mathrm{p} 1=0.034<0.05, \mathrm{p} 2=0.001<0.05)$.

The young people in state-owned enterprises paid the highest attention to issues of social wealth distribution, and showed the most tolerance. In response to the "sky-high remuneration of a few stars", $36.7 \%$ of the youth in state owned enterprises state that "it's understandable as the astronomically high rewards of celebrities are also earned by their labor", which was significantly higher than that of young people working in other units; at the same time, $24.5 \%$ of them considered the "high rewards absurd, which will further widen the gap between the rich and the poor in society". And in the face of colleagues and friends with wealthy family backgrounds and generous spending, $14.3 \%$ of them viewed it as "normal".

\subsection{Significant Differences in Wealth Concept among the Employed Youth with Different Number of Children}

Having different numbers of children has indeed made a difference in the wealth cognition, wealth creation, wealth consumption, and wealth distribution of the employed youth.

\subsubsection{Wealth Perception}

Data analysis suggested that working young people with different numbers of children have demonstrated prominent differences in their cognition of wealth $(\mathrm{p} 1=0.003<0.05, \mathrm{p} 2=0.002<0.05)$.

(1) Young workers with more children were more objective in their cognition of wealth. $54.3 \%$ of the employed youth with more than 2 children agreed more with that "money is the material basis of life, but not the whole of it", $2.4 \%$ higher than those with 1 child and $15.1 \%$ higher than those with none. $77.1 \%$ of the working youth with 2 or more children believed that "material wealth and spiritual wealth are equally important", $7.6 \%$ higher than those with 1 child and $23.6 \%$ higher than those with none.

(2) Young employees with fewer children attached more importance to material wealth such as money. $11 \%$ of working young people with 0 children thought that "money makes the world go around", and $13.6 \%$ of this same group considered that "material wealth out values spiritual wealth as the latter is intangible", both of which are higher than those of the youth with 1 and 1 or more children. 


\subsubsection{Wealth Creation}

Data analysis showed that differences existed in wealth creation among the employed youth with different number of children. In specific terms, there were significant differences in creating wealth through labor $(\mathrm{F}=8.268 \mathrm{p}<0.001)$, making a fortune through breaking the bottom line $(\mathrm{F}=13.892 \mathrm{p}<0.001)$, and becoming the rich second-generation $(\mathrm{F}=4.889 \mathrm{p}<0.001)$; while no difference was noted in marriage into a wealthy family or with a rich beauty $(\mathrm{F}=0.031$ $\mathrm{p}>0.05)$, winning the lottery ( $\mathrm{F}=0.898 \mathrm{p}>0.05)$, and becoming an online celebrity $(\mathrm{F}=0.533 \mathrm{p}>0.05)$.

Young workers with more children were more inclined to become rich through "honest and lawful labor" (M2>M1>M0); and they also revealed more willingness to become the rich second generation if only that would be possible (M2>M1>M0). On the contrary, those with fewer children tended to agree more with that "as long as they can make a fortune, it is acceptable to break the bottom line" (M0>M1>M2).

\subsubsection{Wealth Consumption}

According to data analysis, prominent differences existed in wealth consumption among the employed youth with different number of children. To be specific, there were significant differences in terms of thrift $(\mathrm{F}=11.962 \mathrm{p}<0.001)$, green consumption $(\mathrm{F}=17.267 \mathrm{p}<0.001)$, enjoyment consumption $(\mathrm{F}=3.460 \mathrm{p}<0.05)$ and irrational borrowing consumption $(\mathrm{F}=9.142 \mathrm{p}<0.001)$; and there was no difference in excessive consumption $(\mathrm{F}=0.305 \mathrm{p}>0.05)$.

Young workers with more children are more likely to identify with thrift, green consumption and enjoyment consumption. The more the number of children raised, the higher scores the young employees got in the aspects of "thrift is the traditional virtue of the Chinese nation, and is still worth promoting", "consumers must not only consider their own needs, but should also pay attention to health, green and environmental issues" and "modern men should enjoy life to the full and spend money freely".

\subsubsection{Wealth Distribution}

Data analysis showed that differences were found in wealth distribution among the employed youth with different number of children. Specifically:

(1) The more children the young workers had, the more dispassionate they became about the reality of wealth distribution. When facing "colleagues and friends with wealthy family backgrounds and generous spending", $17.1 \%$ of the employed youth with 2 or more children expressed "highly envious, and I'd like to do the same", higher than those with 0 and 1 child. It can be seen that the more children the young people have, the more eager they become to have a good family environment; meanwhile, they are able to have a clear awareness that "it's normal that we all have our own lives" (77.1\%).

(2) The employed youth with fewer children had a more aggressive mentality of wealth. Young workers with 0 children accounted for $7.7 \%, 5.9 \%, 5.9 \%$, and $15.4 \%$ respectively, in showing their agreement with the following descriptions: "highly jealous and uncomfortable", "indignant and lamenting the unfair fate", "deeply self-abased and feeling worthless" and "the rich second generation is nothing great, I'll work hard to be the rich first generation", which are higher than those with 1 and 2 or more children.

Table 8. Differences in the cognition of wealth creation among the employed youth from different backgrounds (1)

\begin{tabular}{|c|c|c|c|c|c|c|c|}
\hline & & \multicolumn{3}{|c|}{$\begin{array}{c}\text { People should create wealth through } \\
\text { honest and lawful labor }\end{array}$} & \multicolumn{3}{|c|}{$\begin{array}{l}\text { As long as one can make a fortune, it is } \\
\text { acceptable to break the bottom line }\end{array}$} \\
\hline & & M & SD & $\mathrm{T} / \mathrm{F}$ & M & SD & $\mathrm{T} / \mathrm{F}$ \\
\hline \multirow{2}{*}{ Gender } & Male & 4.08 & 1.252 & \multirow{2}{*}{-1.211} & 2.41 & 1.483 & \multirow{2}{*}{$\begin{array}{l}3.815 \\
* * *\end{array}$} \\
\hline & Female & 4.23 & 1.209 & & 1.90 & 1.296 & \\
\hline \multirow{3}{*}{$\begin{array}{l}\text { Political } \\
\text { affiliation }\end{array}$} & Party member & 4.22 & 1.262 & \multirow{3}{*}{2.175} & 1.90 & 1.311 & \multirow{3}{*}{$\begin{array}{l}5.700 \\
* * *\end{array}$} \\
\hline & League member & 4.23 & 1.222 & & 2.14 & 1.426 & \\
\hline & Non-Communist & 3.20 & 1.229 & & 3.70 & 1.418 & \\
\hline
\end{tabular}




\begin{tabular}{|c|c|c|c|c|c|c|c|}
\hline & parties & & & & & & \\
\hline & Independent & 3.80 & 1.436 & & 2.85 & 1.531 & \\
\hline & None & 4.17 & 1.142 & & 2.12 & 1.364 & \\
\hline \multirow[t]{2}{*}{ Only-child or } & Yes & 3.98 & 1.401 & \multirow{2}{*}{$\begin{array}{c}-2.538 \\
* * *\end{array}$} & 2.25 & 1.443 & \multirow{2}{*}{$\begin{array}{c}1.582 \\
*\end{array}$} \\
\hline & No & 4.28 & 1.098 & & 2.04 & 1.372 & \\
\hline \multirow{2}{*}{ Marital status } & No & 4.12 & 1.302 & \multirow{2}{*}{-0.811} & 3.70 & 1.265 & \multirow{2}{*}{$\begin{array}{r}2.644 \\
* * *\end{array}$} \\
\hline & Yes & 4.21 & 1.160 & & 3.84 & 1.167 & \\
\hline \multirow{3}{*}{ Number of } & 0 & 3.99 & 1.358 & \multirow{3}{*}{8.268} & 2.38 & 1.515 & \multirow{3}{*}{13.892} \\
\hline & 1 & 4.44 & 0.945 & & 1.66 & 0.991 & \\
\hline & 2 and above & 4.57 & 0.739 & & 1.77 & 1.285 & \\
\hline \multirow{6}{*}{ Nature of } & State organ & 3.85 & 1.388 & \multirow{6}{*}{2.596} & 2.60 & 1.564 & \multirow{6}{*}{$\begin{array}{c}6.080 \\
* * *\end{array}$} \\
\hline & SOE & 3.84 & 1.546 & & 2.55 & 1.672 & \\
\hline & Public institution & 4.16 & 1.290 & & 1.84 & 1.224 & \\
\hline & Private enterprise & 4.33 & 0.985 & & 1.88 & 1.197 & \\
\hline & Self-employed & 4.18 & 1.260 & & 2.61 & 1.626 & \\
\hline & Others & 4.56 & 0.961 & & 1.68 & 1.030 & \\
\hline
\end{tabular}

Table 8. Differences in the cognition of wealth creation among the employed youth from different backgrounds (2)

\begin{tabular}{|c|c|c|c|c|c|c|c|}
\hline & & \multicolumn{3}{|c|}{$\begin{array}{l}\text { If possible, I'd also like to be a rich } \\
\text { second generation }\end{array}$} & \multicolumn{3}{|c|}{$\begin{array}{l}\text { I am eager to marry into a wealthy family or with a rich } \\
\text { beauty, which is a shortcut to change my destiny }\end{array}$} \\
\hline & & M & SD & $\mathrm{T} / \mathrm{F}$ & M & SD & $\mathrm{T} / \mathrm{F}$ \\
\hline \multirow{2}{*}{ Gender } & Male & 3.76 & 1.277 & \multirow{2}{*}{-0.268} & 3.26 & 1.325 & \multirow{2}{*}{$\begin{array}{l}2.317 \\
* * *\end{array}$} \\
\hline & Female & 3.79 & 1.168 & & 2.98 & 1.190 & \\
\hline \multirow{6}{*}{$\begin{array}{l}\text { Political } \\
\text { affiliation }\end{array}$} & Party member & 3.67 & 1.172 & \multirow{6}{*}{2.056} & 3.06 & 1.208 & \multirow{6}{*}{1.455} \\
\hline & League member & 3.86 & 1.247 & & 3.09 & 1.247 & \\
\hline & Non-Communist & 3.30 & 1.494 & & 3.20 & 1.549 & \\
\hline & parties & & & & & & \\
\hline & Independent & 3.30 & 1.593 & & 3.75 & 1.372 & \\
\hline & None & 3.91 & 1.132 & & 3.05 & 1.270 & \\
\hline
\end{tabular}




\begin{tabular}{|c|c|c|c|c|c|c|c|}
\hline Only-child & Yes & 3.75 & 1.243 & \multirow{2}{*}{-0.388} & 3.35 & 1.328 & \multirow{2}{*}{$\begin{array}{c}3.207 \\
* *\end{array}$} \\
\hline or not & No & 3.79 & 1.200 & & 2.95 & 1.190 & \\
\hline \multirow[t]{2}{*}{ Marital } & No & 3.70 & 1.265 & \multirow{2}{*}{-1.285} & 3.03 & 1.347 & \multirow{2}{*}{-1.122} \\
\hline & Yes & 3.84 & 1.167 & & 3.16 & 1.169 & \\
\hline \multirow{2}{*}{ Number of } & 0 & 3.65 & 1.320 & \multirow{3}{*}{4.889} & 3.10 & 1.335 & \multirow{3}{*}{0.031} \\
\hline & 1 & 3.92 & 1.031 & & 3.08 & 1.089 & \\
\hline children & 2 and above & 4.23 & 0.770 & & 3.14 & 1.240 & \\
\hline \multirow{6}{*}{$\begin{array}{l}\text { Nature of } \\
\text { work unit }\end{array}$} & State organ & 3.45 & 1.346 & \multirow{6}{*}{4.589} & 3.37 & 1.390 & \multirow{6}{*}{1.587} \\
\hline & SOE & 3.41 & 1.553 & & 3.22 & 1.373 & \\
\hline & Public institution & 3.64 & 1.018 & & 2.91 & 1.228 & \\
\hline & Private enterprise & 4.11 & 1.007 & & 3.13 & 1.181 & \\
\hline & Self-employed & 3.80 & 1.386 & & 3.12 & 1.409 & \\
\hline & Others & 3.64 & 1.254 & & 2.72 & 0.737 & \\
\hline
\end{tabular}

Table 8. Differences in the cognition of wealth creation among the employed youth from different backgrounds (3)

\begin{tabular}{|c|c|c|c|c|c|c|c|}
\hline & & \multicolumn{3}{|c|}{$\begin{array}{l}\text { I desire to get rich overnight by winning } \\
\text { the lottery }\end{array}$} & \multicolumn{3}{|c|}{$\begin{array}{c}\text { Becoming an online celebrity is also a way to } \\
\text { get rich quickly }\end{array}$} \\
\hline & & M & SD & $\mathrm{T} / \mathrm{F}$ & M & $\mathrm{SD}$ & $\mathrm{T} / \mathrm{F}$ \\
\hline \multirow{2}{*}{ Gender } & Male & 3.51 & 1.339 & \multirow{2}{*}{1.914} & 3.11 & 1.300 & \multirow{2}{*}{0.047} \\
\hline & Female & 3.26 & 1.347 & & 3.10 & 1.256 & \\
\hline \multirow{5}{*}{$\begin{array}{l}\text { Political } \\
\text { affiliation }\end{array}$} & Party member & 3.18 & 1.352 & \multirow{5}{*}{1.207} & 2.88 & 1.175 & \multirow{5}{*}{$\begin{array}{c}3.914 \\
* *\end{array}$} \\
\hline & League member & 3.51 & 1.279 & & 3.25 & 1.262 & \\
\hline & $\begin{array}{l}\text { Non-Communist } \\
\text { parties }\end{array}$ & 3.40 & 1.776 & & 2.40 & 1.647 & \\
\hline & Independent & 3.50 & 1.357 & & 3.75 & 1.118 & \\
\hline & None & 3.43 & 1.362 & & 3.18 & 1.326 & \\
\hline \multirow{2}{*}{$\begin{array}{l}\text { Only-child or } \\
\text { not }\end{array}$} & Yes & 3.44 & 1.381 & \multirow{2}{*}{0.839} & 3.16 & 1.292 & \multirow{2}{*}{0.703} \\
\hline & No & 3.32 & 1.329 & & 3.07 & 1.263 & \\
\hline
\end{tabular}




\begin{tabular}{|c|c|c|c|c|c|c|c|}
\hline \multirow{2}{*}{ Marital status } & No & 3.33 & 1.362 & \multirow{2}{*}{-0.490} & 3.12 & 1.321 & \multirow{2}{*}{0.209} \\
\hline & Yes & 3.40 & 1.338 & & 3.09 & 1.233 & \\
\hline \multirow{3}{*}{$\begin{array}{l}\text { Number of } \\
\text { children }\end{array}$} & 0 & 3.33 & 1.407 & \multirow{3}{*}{0.898} & 3.11 & 1.321 & \multirow{3}{*}{0.533} \\
\hline & 1 & 3.36 & 1.247 & & 3.04 & 1.160 & \\
\hline & 2 and above & 3.66 & 1.235 & & 3.29 & 1.319 & \\
\hline $\begin{array}{c}\text { Nature of work } \\
\text { unit }\end{array}$ & State organ & 3.38 & 1.379 & 1.852 & 3.17 & 1.342 & 1.368 \\
\hline
\end{tabular}

Note: $* * * \mathrm{p}<0.001, * * \mathrm{p}<0.01, * \mathrm{p}<0.05$

Table 9. Differences in wealth creation among the employed youth from different backgrounds

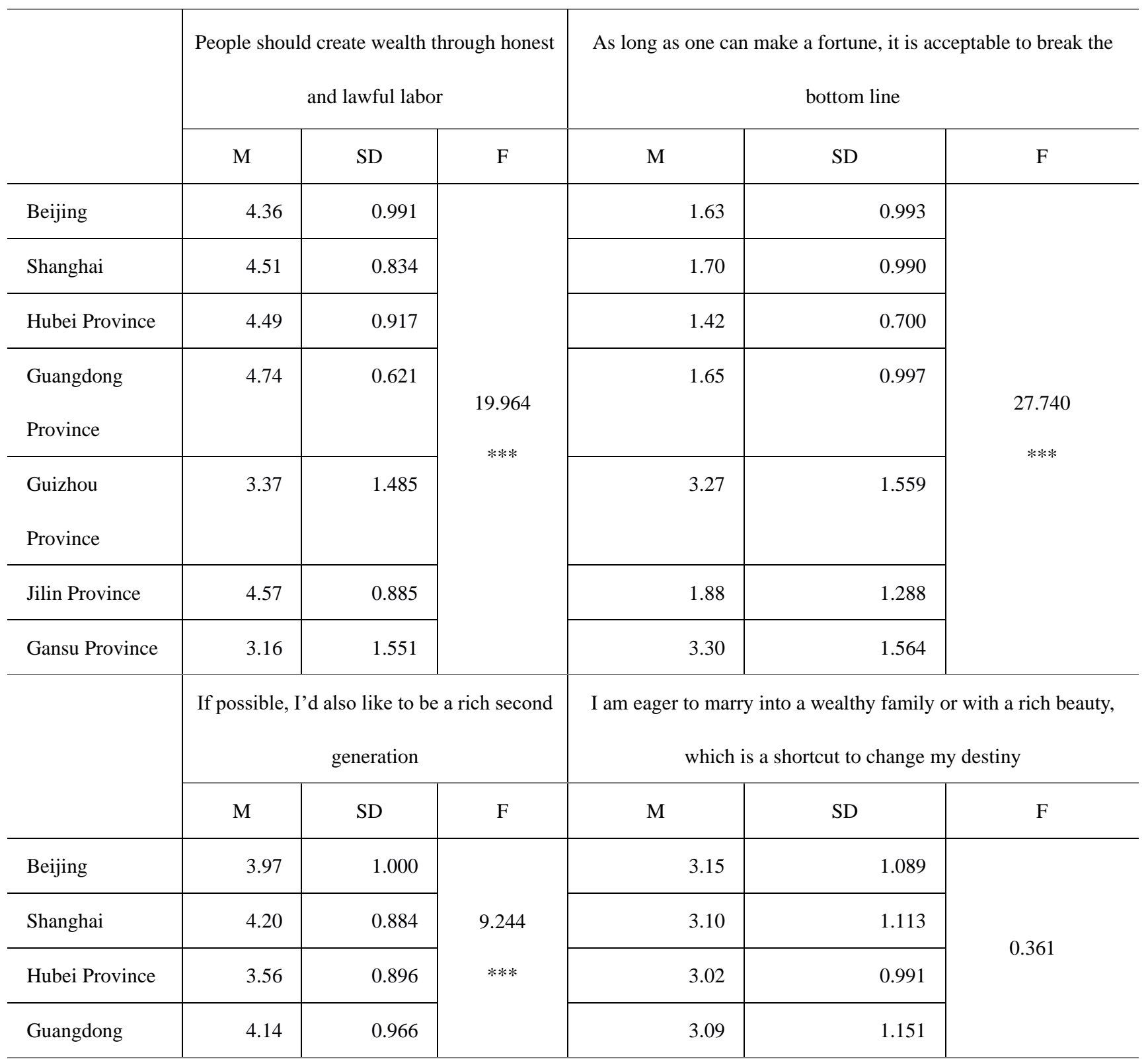




\begin{tabular}{|c|c|c|c|c|c|c|}
\hline \multicolumn{6}{|l|}{ Province } & \\
\hline Guizhou & 3.16 & 1.462 & & 2.98 & 1.594 & \\
\hline \multicolumn{7}{|l|}{ Province } \\
\hline Jilin Province & 4.11 & 1.095 & & 3.07 & 1.202 & \\
\hline \multirow[t]{4}{*}{ Gansu Province } & 3.23 & 1.564 & & 3.28 & 1.572 & \\
\hline & \multirow{2}{*}{\multicolumn{3}{|c|}{ I desire to get rich overnight by winning }} & \multirow{2}{*}{\multicolumn{3}{|c|}{ Becoming an online celebrity is also a way to get rich quickly }} \\
\hline & & & & & & \\
\hline & M & SD & $\mathrm{F}$ & M & SD & $\mathrm{F}$ \\
\hline Beijing & 3.25 & 1.278 & \multirow{9}{*}{1.398} & 2.97 & 1.080 & \multirow{9}{*}{1.364} \\
\hline Shanghai & 3.52 & 1.145 & & 3.28 & 1.110 & \\
\hline Hubei Province & 3.31 & 1.055 & & 2.92 & 0.952 & \\
\hline Guangdong & 3.63 & 1.328 & & 3.26 & 1.093 & \\
\hline Province & & & & & & \\
\hline Guizhou & 3.24 & 1.512 & & 2.92 & 1.571 & \\
\hline \multicolumn{5}{|l|}{ Province } & & \\
\hline Jilin Province & 3.58 & 1.451 & & 3.06 & 1.342 & \\
\hline Gansu Province & 3.08 & 1.563 & & 3.38 & 1.572 & \\
\hline
\end{tabular}

Note: $* * * \mathrm{p}<0.001, * * \mathrm{p}<0.01,{ }^{*} \mathrm{p}<0.05$

Table 10. Differences in the wealth consumption among the employed youth from different backgrounds (1)

\begin{tabular}{|c|c|c|c|c|c|c|c|}
\hline & & \multicolumn{3}{|c|}{$\begin{array}{l}\text { Thrift is the traditional virtue of the } \\
\text { Chinese nation, which is still worth } \\
\text { promoting }\end{array}$} & \multicolumn{3}{|c|}{$\begin{array}{l}\text { Consumers must not only consider their own needs, } \\
\text { but should also pay attention to health, green and } \\
\text { environmental issues }\end{array}$} \\
\hline & & M & $\mathrm{SD}$ & $\mathrm{T} / \mathrm{F}$ & M & $\mathrm{SD}$ & $\mathrm{T} / \mathrm{F}$ \\
\hline \multirow{2}{*}{ Gender } & Male & 4.05 & 1.299 & \multirow{2}{*}{$\begin{array}{c}-1.223 \\
* *\end{array}$} & 4.10 & 1.260 & \multirow{2}{*}{$\begin{array}{c}-2.179 \\
* *\end{array}$} \\
\hline & Female & 4.19 & 1.081 & & 4.34 & 1.052 & \\
\hline \multirow{3}{*}{$\begin{array}{l}\text { Political } \\
\text { affiliation }\end{array}$} & Party member & 4.22 & 1.186 & \multirow{3}{*}{1.972} & 4.36 & 1.033 & \multirow{3}{*}{1.892} \\
\hline & League member & 4.04 & 1.208 & & 4.19 & 1.139 & \\
\hline & Non-Communist & 3.30 & 1.767 & & 3.40 & 1.897 & \\
\hline
\end{tabular}




\begin{tabular}{|c|c|c|c|c|c|c|c|}
\hline & parties & & & & & & \\
\hline & Independent & 3.90 & 1.447 & & 4.20 & 1.436 & \\
\hline & None & 4.20 & 1.037 & & 4.19 & 1.160 & \\
\hline \multirow{2}{*}{$\begin{array}{c}\text { Only-child } \\
\text { or not }\end{array}$} & Yes & 3.96 & 1.341 & \multirow{2}{*}{$\begin{array}{c}-2.417 \\
* *\end{array}$} & 4.08 & 1.249 & \multirow{2}{*}{$\begin{array}{c}-2.178 \\
*\end{array}$} \\
\hline & No & 4.24 & 1.061 & & 4.32 & 1.079 & \\
\hline \multirow{2}{*}{$\begin{array}{l}\text { Marital } \\
\text { status }\end{array}$} & No & 3.98 & 1.281 & \multirow{2}{*}{$\begin{array}{c}-2.555 \\
* *\end{array}$} & 4.09 & 1.264 & \multirow{2}{*}{$\begin{array}{c}-2.430 \\
*\end{array}$} \\
\hline & Yes & 4.27 & 1.068 & & 4.36 & 1.026 & \\
\hline \multirow{3}{*}{$\begin{array}{c}\text { Number of } \\
\text { children }\end{array}$} & 0 & 3.92 & 1.330 & \multirow{3}{*}{$\begin{array}{c}11.962 \\
* * *\end{array}$} & 4.03 & 1.282 & \multirow{3}{*}{12.614} \\
\hline & 1 & 4.46 & 0.787 & & 4.53 & 0.835 & \\
\hline & 2 and above & 4.54 & 0.701 & & 4.71 & 0.572 & \\
\hline \multirow{7}{*}{ Nature of } & State organ & 3.95 & 1.254 & \multirow{7}{*}{0.762} & 3.95 & 1.227 & \multirow{7}{*}{$\begin{array}{c}3.178 \\
* *\end{array}$} \\
\hline & SOE & 4.08 & 1.152 & & 3.90 & 1.373 & \\
\hline & Public & 4.17 & 1.184 & & 4.36 & 1.124 & \\
\hline & institution & & & & & & \\
\hline & Private & 4.21 & 1.041 & & 4.42 & 0.901 & \\
\hline & Self-employed & 3.98 & 1.543 & & 4.00 & 1.470 & \\
\hline & Others & 4.32 & 1.030 & & 4.40 & 1.000 & \\
\hline
\end{tabular}

Table 10. Differences in the wealth consumption among the employed youth from different backgrounds (2)

\begin{tabular}{|c|c|c|c|c|c|c|c|c|c|c|}
\hline & & \multicolumn{3}{|c|}{$\begin{array}{l}\text { Consumption is spending } \\
\text { today's money to realize } \\
\text { tomorrow's dreams }\end{array}$} & \multicolumn{3}{|c|}{$\begin{array}{l}\text { Modern men should enjoy life } \\
\text { to the full and spend money } \\
\text { freely }\end{array}$} & \multicolumn{3}{|c|}{$\begin{array}{l}\text { Naked Loan is } \\
\text { understandable in order to } \\
\text { buy favorite items }\end{array}$} \\
\hline & & M & SD & $\mathrm{T} / \mathrm{F}$ & $\mathrm{M}$ & SD & $\mathrm{T} / \mathrm{F}$ & M & $\mathrm{SD}$ & $\mathrm{T} / \mathrm{F}$ \\
\hline \multirow{2}{*}{ Gender } & Male & 2.93 & 1.284 & \multirow{2}{*}{1.313} & 3.00 & 1.321 & \multirow{2}{*}{0.878} & 2.41 & 1.547 & \multirow{2}{*}{$\begin{array}{l}2.944 \\
* * *\end{array}$} \\
\hline & Female & 2.77 & 1.239 & & 2.90 & 1.153 & & 2.02 & 1.274 & \\
\hline \multirow{3}{*}{$\begin{array}{l}\text { Political } \\
\text { affiliation }\end{array}$} & Party member & 2.79 & 1.172 & \multirow{3}{*}{1.459} & 2.88 & 1.234 & \multirow{3}{*}{2.304} & 2.12 & 1.312 & \multirow{3}{*}{$\begin{array}{r}4.453 \\
* *\end{array}$} \\
\hline & League member & 2.81 & 1.235 & & 2.96 & 1.135 & & 2.14 & 1.398 & \\
\hline & Non-Communist & 3.50 & 1.650 & & 3.40 & 1.713 & & 3.80 & 1.751 & \\
\hline
\end{tabular}




\begin{tabular}{|c|c|c|c|c|c|c|c|c|c|c|}
\hline & parties & & & & & & & & & \\
\hline & Independent & 3.30 & 1.750 & & 3.65 & 1.387 & & 2.75 & 1.743 & \\
\hline & None & 2.81 & 1.254 & & 2.86 & 1.213 & & 2.10 & 1.379 & \\
\hline \multirow[t]{2}{*}{ Only-child } & Yes & 2.84 & 1.231 & \multirow{2}{*}{-0.054} & 3.05 & 1.214 & \multirow{2}{*}{1.428} & 2.25 & 1.483 & \multirow{2}{*}{0.711} \\
\hline & No & 2.84 & 1.279 & & 2.88 & 1.234 & & 2.15 & 1.365 & \\
\hline \multirow[t]{2}{*}{ Marital } & No & 2.92 & 1.292 & \multirow{2}{*}{1.216} & 3.04 & 1.299 & \multirow{2}{*}{1.580} & 2.39 & 1.535 & 2.895 \\
\hline & Yes & 2.77 & 1.229 & & 2.85 & 1.157 & & 2.00 & 1.264 & $* * *$ \\
\hline \multirow{3}{*}{ Number of } & 0 & 2.88 & 1.314 & \multirow{3}{*}{0.305} & 3.06 & 1.308 & \multirow{3}{*}{3.460} & 2.41 & 1.548 & \multirow{3}{*}{9.142} \\
\hline & 1 & 2.77 & 1.147 & & 2.73 & 1.060 & & 1.81 & 1.024 & \\
\hline & 2 and above & 2.83 & 1.248 & & 2.83 & 1.071 & & 1.89 & 1.183 & \\
\hline \multirow{6}{*}{$\begin{array}{l}\text { Nature of } \\
\text { work unit }\end{array}$} & State organ & 2.97 & 1.314 & \multirow{6}{*}{1.108} & 3.17 & 1.380 & \multirow{6}{*}{1.365} & 2.53 & 1.512 & \multirow{6}{*}{$\begin{array}{r}3.796 \\
* *\end{array}$} \\
\hline & SOE & 3.02 & 1.250 & & 3.24 & 1.315 & & 2.65 & 1.640 & \\
\hline & Public institution & 2.60 & 1.250 & & 2.86 & 1.276 & & 2.19 & 1.382 & \\
\hline & Private enterprise & 2.90 & 1.192 & & 2.85 & 1.096 & & 1.94 & 1.243 & \\
\hline & Self-employed & 2.84 & 1.433 & & 2.90 & 1.330 & & 2.35 & 1.534 & \\
\hline & Others & 2.76 & 1.200 & & 2.80 & 0.957 & & 1.64 & 1.075 & \\
\hline
\end{tabular}

Note: $* * * p<0.001, * * \mathrm{p}<0.01, * \mathrm{p}<0.05$

Table 11. Differences in wealth consumption among the employed youth from different backgrounds

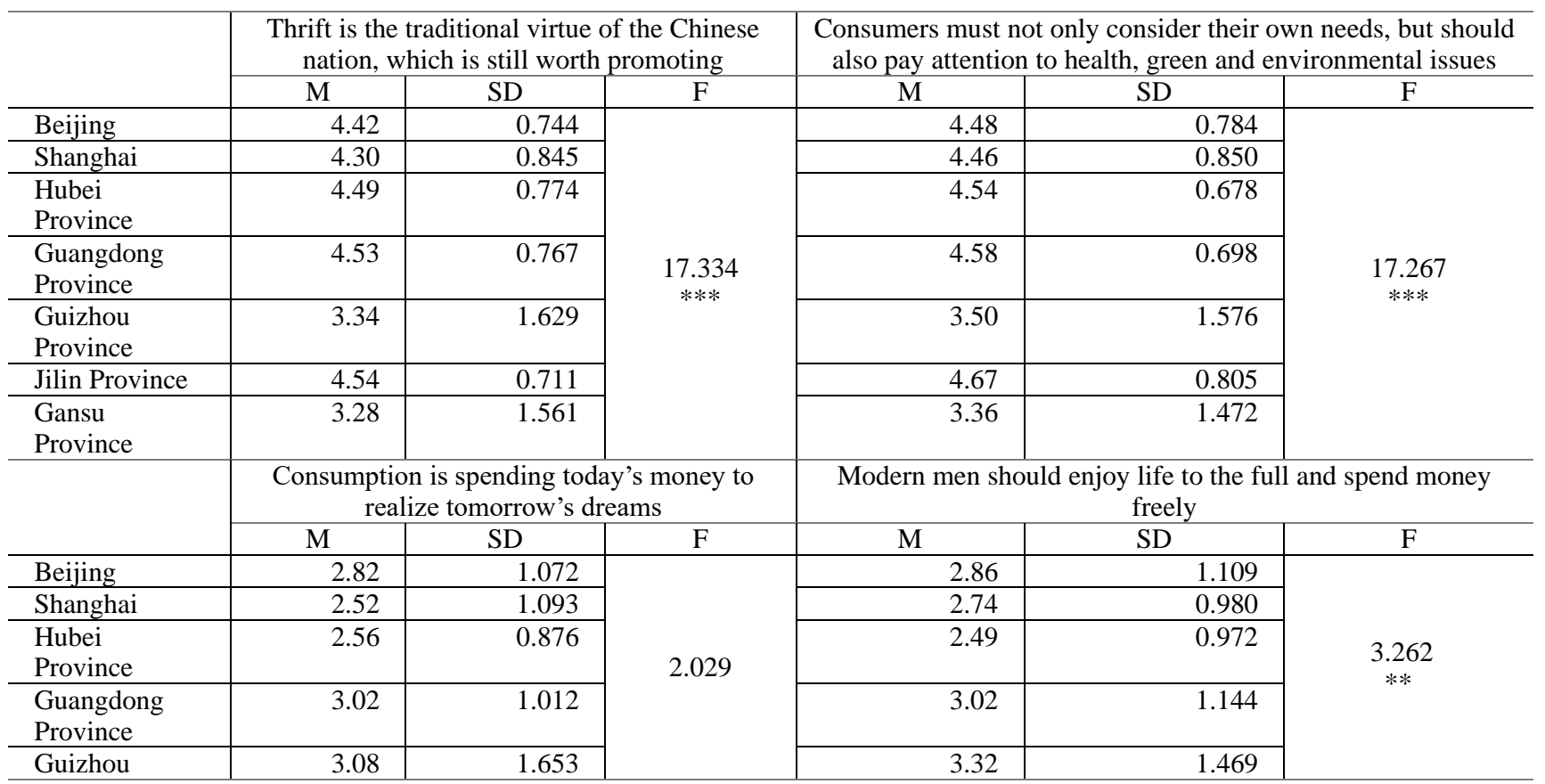




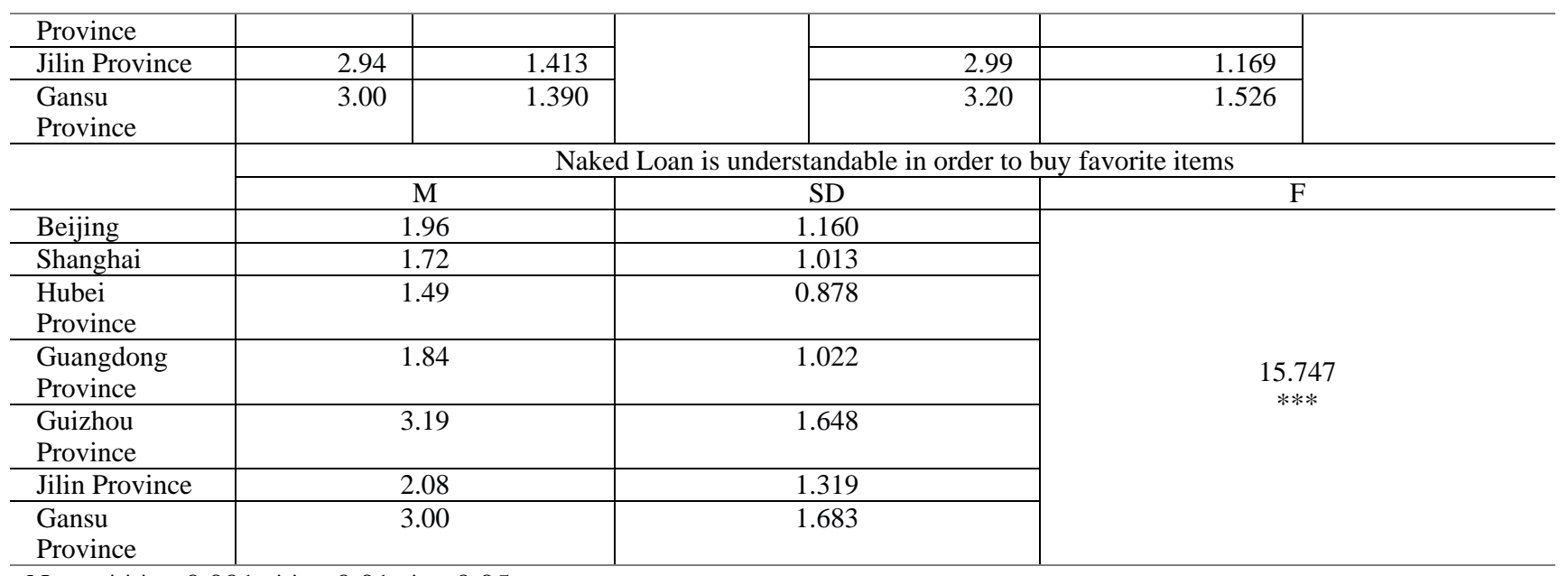

Note: $* * * p<0.001, * * \mathrm{p}<0.01, * \mathrm{p}<0.05$

\section{Analysis of Influencing Factors on the Wealth Concept of the Employed Youth}

In this study, multiple choice question "Which of the following do you think are the main factors influencing the formation of your wealth concept, and rank them in order of their influence from large to small", and single choice question "Which of the following groups do you think have the greatest influence on your wealth concept" were designed to help analyze the factors influencing young people's view on wealth.

\subsection{The Complicated Social Environment}

The growth and development of youngsters is inseparable from the society which also shapes their outlook on wealth as they enter the workforce and afterwards. The survey suggested that $71.75 \%$ of the respondents said that the "social environment" is the primary factor affecting the wealth concept of working youth nowadays. Further investigation revealed that market economy and western concept of wealth are the two major factors influencing the wealth concept of the employed youth.

Market economy is the main internal factor affecting the wealth concept of young employees in China. The construction of a socialist market economy provided space for the flow of wealth (Dianxia Ning, 2018). At the same time, the profit-seeking nature of the market economy itself has also stimulated the infinite desire of young people for wealth. With the individual's pursuit of material benefits being maximized, money, as an intermediary linking the exchange of commodities, is naturally regarded as the embodiment of wealth and commodity, which has given the illusion to some youths that they could have everything if they have money. This concept then leads to the infinite worship and unlimited pursuit of money, which is ultimately manifested as money worship. Along with this, hedonism, egoism, utilitarianism, etc., also emerged as the times require, and some young people exposed to their influence are blindly pursuing material wealth, and have become the driving force behind the deterioration of social morals.

Amid the reform and opening up and economic globalization, the spread and infiltration of some erroneous thoughts from the west is an important external cause for the deviation of youth's view of wealth. With the opening of China's door, the money-centric view of wealth and self-centered values advocated by the west have flooded into our country. Playing on young people's curiosity and immaturity, these values have invaded their minds wantonly under the cloak of seemingly plausible reason, thus influencing their value judgment and the formation of wealth concept. Some young workers, impacted by these wrong thoughts, have seen their understanding of wealth and relevant behavior westernized to varying degrees, showing a stronger egoism and profit-seeking trend. Some of them even resort to unscrupulous means to meet their own interests, which not only greatly limits the space for young people to pursue the meaning of life, but also hinders the long-term development of the society and country. In this course, some of their views on wealth are gradually alienated in the infinite pursuit of material wealth and personal interests.

\subsection{The Influence of Personal Cognition and Thinking Mode}

The view on wealth is closely related to the cognition and thinking mode of young people. Youth is a period of transition from childhood to adulthood, during which our needs undergo the richest and most diversified development, showing significantly complicated and multiple features (Junyan Liu, 2014). This characteristic of the youth determines that their cognition and thinking mode are somehow restrained. The survey showed that $70.62 \%$ of the respondents said that "personal cognition and thinking mode" were the most core factor affecting the wealth view of young employees. 
The wealth concept falls into the category of values and is deeply influenced by one's own cognition and way of thinking. Working young people aged 14-35 have just left the ivory tower and entered the society. Their mentality and experience are still inadequate, and thus they cannot judge certain wealth-related social phenomena comprehensively and rationally. They are easily influenced by the outside world and others when looking at and analyzing wealth issues. The survey revealed that $18.91 \%$ of the respondents stated that the superiors and colleagues around them were the groups that had the most influence on their wealth concept. As the youth expand their social circles and become more mature psychologically, they are having wider horizons and growing more active and open in thinking than before. They have become more aware of, and often comment on, various social phenomena, especially those related to (money) wealth. However, limited by subjective cognition and objective conditions, their views on wealth are inevitably influenced by the concepts of money worship, consumerism, hedonism and so on.

\subsection{Absence of Wealth Education}

Education is an important channel to shape young people's world view, outlook on life and values, while home and school are two important places to carry out it. According to the survey, 65.6 percent of respondents said the education they received (including family education and school education) was the main factor influencing their concept of wealth.

The education received by young people before they entered the workplace has laid a preliminary foundation for the formation of their wealth concept. However, this concept is not static, and the long-term absence of education on it easily leads to related problems among youngsters. The survey showed that when asked about "Does your family attach importance to wealth education", $26.88 \%$ of the respondents answered "Yes, greatly", $40.09 \%$ said "Yes", 30.75\% responded "No", and 2.28\% replied "Never thought about it". It suggested that although most working young people's families attached importance to the education of wealth concept, there were still about $30 \%$ of the families falling behind in this regard. In addition, in view of "whether your company has carried out educational activities related to wealth concept, such as integrity education, awareness campaign, etc., and what is the effect?" $48.06 \%$ of the respondents stated that they "have never participated in such educational activities" and $25.74 \%$ said "yes, but the effect is not great", and only $23.92 \%$ expressed "yes, and the effect is great", which shows the current wealth education carried out by the companies is not ideal.

\subsection{The Impact of Internet Culture}

The rapid development of Internet information technology has brought about tremendous changes to people's lifestyles, values, and communication channels. As the largest group of Internet users, young people have witnessed their values and wealth concepts increasingly affected by the internet culture and presenting diversified characteristics gradually. According to the survey, $41.91 \%$ of the respondents believed that the current network environment is a major factor impacting their wealth concept.

Internet culture is a double-edged sword. On the one hand, it broadens the horizons and communication channels of the employed youth and provides them with convenient and effective information support; on the other hand, it also pounds their ideology and value orientation with confusion. In their course of online interaction, working young people's wealth concept is also exposed to a myriad of positive and negative information, showing a personalized, diversified, and secular trend. "Poverty limits my imagination", "rich and willful", "rich redneck, let's be friends" and other Internet buzzwords also reflect new changes in the wealth outlook of the youth under the impact of internet culture.

\section{Conclusion}

At present, the mainstream of the working youth's wealth concept in China is positive. In terms of wealth cognition, most employed youths can evaluate money objectively and view the relationship between material and spiritual wealth properly, with a few of them having a tendency towards money worship and material supremacy. In terms of wealth creation, most young workers advocate creating wealth through labor while also pay attention to the role of innovation and technology in wealth creation, with a few having the mentality of reaping without sowing and getting rich overnight. In terms of wealth consumption, most of the employed youth stick to thrift and follow green consumption, with a few having enjoyment and extravagant consumption behavior. And in terms of wealth distribution, the majority of those youths can view the distribution of social wealth objectively and rationally and emphasize "distribution according to contribution", while a few are jealousy, envious, and hateful towards the rich.

Demographic factors such as gender, region, nature of work unit, and number of children have significant effects on the wealth concept of the employed youth. Specifically, (1) in the aspect of wealth cognition, men are more likely than women to value material wealth such as money, and are more inclined to get rich quickly or by unscrupulous means; and regarding wealth consumption, women identify more with thrift and pay more attention than men to green consumption such as environmental protection and health. (2) Young people from Beijing are more objective in their cognition of wealth; those from Jilin Province are more advocating for getting rich through hard work and thrift in terms of wealth 
creation and consumption; and those from Hubei Province hold a more balanced and rational view in the distribution of wealth. (3) In terms of wealth cognition, young people working for public institutions are more objective and rational, while those self-employed youths value material wealth more; in terms of wealth creation, young men in private enterprises attach more importance to getting better off through labor, while those self-employed report the highest proportion in getting wealthy by all means; and in terms of wealth consumption, the young people of state-owned enterprises concerned themselves more with the reality of social distribution and keep a more peaceful and calm mentality about wealth. (4) The more children young employees have, the more objective and rational they are in viewing wealth regarding wealth cognition, more inclined to get rich through hard work in wealth creation, more identified with thrift and green consumption in terms of wealth consumption, and more cool-headed in looking at the reality of social wealth distribution.

The possible influencing factors for the differences and problems in the wealth concept of the employed youth in China presently are: the complex social environment, the differences in personal cognition and thinking modes, the absence of wealth education at home and school, and the impact of internet culture.

\section{References}

CAITEC. (2018). The Road to Consumption Development and Upgrade--The 40's anniversary of China's reform and opening up. Beijing, BJ:China Commerce and Trade Press.

CPCCC \& State Council (2017, April 14). The National Medium and Long-term Youth Development Plan (2016-2025). People's Daily, p.A1.

Dianxia, N. (2018). The evolution of China's wealth concept in the past 40 years of reform and opening up and the reflection on its modernity. Teaching and Research, 18(9), 21-29.

Hegel, G. W. F. (2009). Principles of Legal Philosophy. Beijing, BJ: The Commercial Press.

Junyan, L. (2014). An analysis of the needs and characteristics of contemporary youth. Journal of China Youth University for Political Sciences, 33(04), 1-7.

Xianda, C. (2010). The view of wealth from the perspective of historical materialism. Philosophical Research, 10(10), 24-31.

\section{Copyrights}

Copyright for this article is retained by the author(s), with first publication rights granted to the journal.

This is an open-access article distributed under the terms and conditions of the Creative Commons Attribution license which permits unrestricted use, distribution, and reproduction in any medium, provided the original work is properly cited. 